\title{
Kinetic Properties of Pyruvate Kinase in Human Maternal Leukocytes in Fetal Malnutrition
}

\author{
MOSTAFA S. MAMEESH, JACK METCOFF, ${ }^{38}$ 'PAUL COSTILOE, AND WARREN CROSBY \\ Departments of Pediatrics, Biochemistry and Molecular Biology, and Gynecology and Obstetrics, University of \\ Oklahoma Health Sciences Center and Children's Memorial Hospital, Oklahoma City, Oklahoma, USA
}

\section{Extract}

Pyruvate kinase $(P K)$ is one of the regulatory enzymes in glycolysis. The present study was undertaken to determine whether regulation of the enzyme by normally occurring metabolites was disturbed in leukocytes of mothers who delivered fetally malnourished (FM) babies. Kinetic studies of enzyme regulation by physiologic effectors approximates a potential regulating mechanism of the enzyme in its cellular environment. There are two isoenzymes of PK. Leukocytes contain an $M_{2}$ enzyme with intermediate regulatory properties between the liver (type $L$ ) and the muscle (type $M$ ) enzymes. The presence in the cell of $M_{2} P K$ in the A form leads to inhibition of glycolysis by amino acids, such as alanine, and, therefore, to the sparing of glucose but probable inhibition of energy production from glucose. In this study, leukocytes were isolated from blood of six pregnant women and 11 women in the postpartum period in Oklahoma and at parturition from 31 women in Mexico. Fourteen of the latter group delivered FM babies. The kinetic characteristics of the nonpurified enzyme PK with respect to allosteric modulation by fructose-1,6-phosphate (FDP) and $\mathbf{L}$-alanine (Ala) were studied in the leukocyte extracts. Data for initial reaction velocities ( $v$ ) vs substrate concentrations (s), double reciprocal Lineweaver-Burk plots, and Hill plots are presented. The equations for the double reciprocal plots were determined by linear regression analysis. The enzyme constants were derived by computer, and the values compared by the Mann-Whitney $U$-test. In all subjects studied, $0.5 \mathrm{mM}$ FDP activated and $2 \mathrm{mM}$ L-alanine inhibited the enzyme. During pregnancy, the $v$ vs s concentration curves were hyperbolic (Hill coefficient, $n<1.0$ ) except for the Ala-inhibited enzyme during pregnancy, which had a sigmoid curve, $n=1.54$. The interaction of FDP and Ala was dependent on the concentration of the substrate phosphocnolpyruvate (PEP) at low $[P E P]$. There was net activation, not inhibition, at high concentrations; the switchover was at $0.5 \mathrm{mM}$ PEP during pregnancy. In Mexican mothers having normal babies (normal mothers) the maximum initial velocity, $\mathrm{V}$ (micromoles per min per $\mathrm{mg}$ of $\mathrm{DNA}$ ), with respect to $\mathrm{PEP}$, was $2.22 \pm 0.34$; in $\mathrm{FM}$ mothers, $\mathrm{V}$ was 2.01 \pm 0.44. With respect to binding of the substrate, PEP, $V$ of the leukocyte enzymes in FM mothers vs normal mothers was equally inhibited by Ala ( $\Delta V=-50 \% v s-47 \%)$, but was significantly less responsive to stimulation by $\mathrm{FDP}(\Delta \mathrm{V}=+10 \% v s+75 \%)$. When both Ala and FDP were present, FDP less effectively overcame the inhibiton by Ala $(\Delta V=-9 \%$ v $+54 \%)$.

The $K_{0.05}$ of the enzyme (molar concentration $\times 10{ }^{4}$ PE.P) was significantly reduced by FDP, whether Ala was present or not, during pregnancy and in the postpartum period in leukocytes of Oklahoma mothers and at term in Mexican mothers. The $K_{0.5}$ for normal and FM mothers was similar.

Thus, the enzyme in leukocytes of Mexican mothers who delivered FM and normal babies exhibited different kinetic responses to the allosteric modulators. If similar changes were present throughout pregnancy, the reduced response of the enzyme to stimulation by FDP could lead to a reduction in available metabolic energy required by rapidly replicating cells, like leukocytes, and by cells of the growing fetus.

\section{Speculation}

It is likely that the rate of cellular glycolysis is determined, in part, by the allosteric modulators of enzyme activities, such as the interaction of the metabolites, FDP and Ala. Thus, if the significantly reduced sensitivity of pyruvate kinase to activation by FDP observed in the leukocytes of mothers also occurs in fetal cells it could reduce glucose utilization, energy production, and, consequently, cell division and growth. Modulation of the activity of susceptible key enzymes by some imbalance of normally occurring nutrients could lead to fetal malnutrition without obvious nutrient deficiency in the mother. Response of leukocyte enzymes to allosteric effectors may provide a useful test to identify mothers of FM babies prenatally.

Peripheral blood leukocytes are being employed increasingly as an easily accessible tissue composed of nucleated cells whose me tabolism reflects that of other tissue cells $(1,2,15)$. For example, it was reported previously from this laboratory that pyruvate kinase activity (ATP: pyruvate phosphotransferase. EC. 3.7.1.40) was reduced in muscle cells $(17,18)$ and in peripheral blood leukocytes $(30,31)$ of infants with severe protein-calorie malnutrition ( $k$ washiorkor). The decreased activity of PK in muscle cells of severely malnourished children was attributed to an allosteric change in the affinity of the enzyme for its activating metal ion. $\mathrm{K}$, in the presence of very high levels of intracellular $\mathrm{Na}^{\circ}$ (18). Later. we reported that the activity of this encyme and of adenyate kinase in cord blood leukocytes was reduced in infants born small for gestational age with characteristics of fetal malnutrition. Activities of these enzymes and the levels of the adenine nucleotides also were reduced in the leukocytes of the mothers of these FM babies $(19,32)$. The activity of RNA polymerase in leukocytes of mothers who delivered low birthweight babies also decreased. A positive correlation between leukocyte RNA polymerase activity and weight of the baby at birth was noted (20). Neither activities of those enzymes, protein synthesis $\left({ }^{3} \mathrm{H}\right.$-leucine incorporation). nor adenine nucleotide levels were reduced in the small placentas of the FM babies. Recently, decreased maximal enzyme activity for PK with respect to its substrates, PEP and ADP, was found in leukocytes of mothers who delivered FM babies (16). Since maternal leukocyte PK appeared to be adversely affected in mothers of FM babies, the present study was undertaken to determine whether regulation of the enzyme by normally occurring metabolites was disturbed.

Pyruvate kinase is one of the regulatory enzymes in glycolysis Two major isoenzymes occur in mammalian tissues. Type $\mathrm{L}$ (liver) is present in liver parenchymal cells and erythrocytes, whereas type $M$ (muscle) occurs in muscle and leukocytes $(21,25)$. The L-isoenzyme is allosterically modified by PEP, ATP, K+ FDP. 
and Ala, whereas the type $\mathrm{M}$ enzyme is considered nonallosteric on the basis of its Michaelis-Menten kinetics $(3,6)$. Recent reports. however. indicate that leukocytes contain an M-type pyruvate kinase, designated $\mathbf{M}_{2}$, which exhibits intermediate regulatory properties between the liver (type $L$ ) and the muscle (type $M$ ) enzymes (26). The $\mathrm{M}_{2}$-type enzyme exists in two interconvertible forms, called $\mathrm{A}$ and $\mathrm{B}$, which exhibit different kinetic properties (27). Van Berkel et al. (28) suggest that the presence in the cell of $\mathrm{M}_{2}$ PKA leads to inhibition of glycolysis by amino acids, such as alanine, and, therefore, to the sparing of glucose. which can be of importance during limited carbohydrate intake. The studies reported in this communication support the view that PK activity of leukocytes during pregnancy and post-partum, like the $M_{2}$ type $A$ enzyme, is regulated by the allosteric modifiers, FDP and Ala.

\section{METHODS}

\section{SUBJECTS}

Blood was collected by venipuncture with informed consent from six volunteer pregnant women at 2432 weeks of pregnancy at the OB-Gyn Clinic. University of Oklahoma Health Sciences Center, Oklahoma City, and from 11 women at 3 days to 6 weeks postpartum. All of these women delivered normally grown babies. In additional studies performed during a 2 -month period (January and February 1974), blood samples were obtained at parturition from 14 mothers who delivered FM babies and from 17 mothers who had normal babies in Mexico. All of these mothers were delivered at the Hospital de Ginecologia y Obstetricia no. 2 of the Instituto Mexicano del Seguro Social and the Centro Medico Nacional, Mexico, D.F. The mothers of the FM babies did not appear to be more malnourished than the mothers of the normal babies.

\section{LEUKOCYTE PREPARATIONS}

Leukocytes were isolated at $4^{\circ}$ within $2 \mathrm{hr}$ by sedimentation of the erythrocytes with the aid of dextran, as previously described $(19,32)$, except that the leukocytes were washed twice with Hank's solution and suspended in $80 \mathrm{mM} \mathrm{KCl}$ and $5 \mathrm{mM}$ Tris- $\mathrm{HCl}$ buffer, $\mathrm{pH} \mathrm{7.4.} \mathrm{This} \mathrm{suspension} \mathrm{was} \mathrm{quickly} \mathrm{frozen} \mathrm{and} \mathrm{thawed.} \mathrm{then}$ homogenized, in a Potter-Elvehjem glaiss homogenizer fitted with a Teflon pestle with 10 up and down strokes at $500 \mathrm{rpm}$ and $4^{\circ}$.

The homogenate was centrifuged for $10 \mathrm{~min}$ at $5,000 \times \mathrm{g}$ and the clear supernatant was used as the source of the enzyme. Leukocytes prepared in this manner were essentially free of erythrocytes and were predominantly granulocytes $(8090 \%)$. The DNA content of the leukocyte suspensions $(0.43 \pm 0.08 \mathrm{mg} / \mathrm{ml})$ and the protein content of the enzyme extracts $(3.69 \pm 0.73 \mathrm{mg} / \mathrm{ml})$ were similar in all subjects. The enzyme activity was expressed and presented in this report on the basis of DNA content (activity per $\mathrm{mg}$ of cell nuclei), rather than the more common expression of activity per $\mathrm{mg}$ of protein. The protein to DNA ratios for the leukocyte extracts of all groups were similar. The enzyme extracts from several normal and FM leukocyte samples showed one band of activity which corresponded to the M-type isoenzyme by cellulose acetate electrophoresis (24). The concentration of alanine in maternal leukocytes approximates $300 \mu \mathrm{mol} / \mathrm{g}$ DNA. No significant differences were found between levels in leukocytes of mothers having normal or FM babies (29). Since PK in leukocyte extracts begins to lose appreciable amounts of activity after several hours, the kinetic analyses were begun immediately after the extracts were prepared. The small volume $(<200 \mu)$ and limited amount of time precluded protracted dialysis of the extracts to remove small quantities of effectors which might have been present in the cells.

\section{ENZYME ASSAY}

Pyruvate kinase activity was measured according to the method of Bucher and Pfleiderer (4) by observing the decrease in absorbance at $340 \mathrm{~nm}$ in a coupled reaction with lactate dehydro- genase at $30^{\circ}$ and $\mathrm{pH} 7.4$ in a Gilford spectrophotometer equipped with a temperature-controlled cell chamber. automatic multisample changer, and chart recorder. The final reaction mixture contained $80 \mathrm{mM}$ Tris-HCl buffer, $\mathrm{Ph}$ 7.4: $80 \mathrm{mM} \mathrm{KCl}: 0.2 \mathrm{mM}$ $\mathrm{NADH}_{2}, 2.0 \mathrm{mM}$ ADP: $20 \mathrm{mM}$ nicotinamine: $8 \mathrm{mM} \mathrm{MgSO}_{4}: 10$ units/ml lactate dehydrogenase: and $0.6 \mathrm{mg} / \mathrm{ml}$ bovine serum albumin. The concentrations of PEP used to obtain the velocity curves were from 0.05 to $2 \mathrm{mM}$. Where added. the concentration of FDP was $0.5 \mathrm{mM}$ and of $\mathrm{L}$-alanine, $2.0 \mathrm{mM}$. The reaction was started by the addition of the encyme extract. Appropriate blanks were run simultaneously to demonstrate the presence or absence of significant side reactions. Analyses were always completed within $12 \mathrm{hr}$ after blood was obtained. Protein was determined by the Lowry procedure (13), using bovine serum albumin as standard. and DNA was estimated by the diphenylamine reaction as described by Burton(5) and modified by Giles and Mever (9).

ADP, PEP. NADH, FDP, and L-Ala were purchased from Sigma and lactate dehydrogenase was obtained from Boehringer. All other reagents were of analytic grade and were prepared in glass bidistilled water.

\section{RESULTS}

The effect of FDP and Ala on the pyruvate kinase activity in leukocyte extracts prepared from blood samples obtained at $24 \quad 32$ weeks of pregnancy as a function of PEP concentration is illustrated in Figure 1. The data on leukocytes prepared from blood samples withdrawn from subjects during the early postpartum period ( 3 days to 6 weeks) are similarly presented in Figure? Initial reaction velocity $(v)$ vs substrate concentration ([PEP] =$[\mathrm{S}]$ ) curves, double reciprocal Lineweaver-Burk plots, and Hill plots are presented in the figures. The equations for the lines in the $1 / v$ vs 1 / [PEP] plots were determined by linear regression analysis and the enzyme constants were derived by computer. The initial reaction velocity $v s$ substrate concentration curves are hyperbolic (Hill coefficient $n \leq 1.0$ ). except in the Ala-inhibited ensume during pregnancy, which had a sigmoid curve, $n=1.54$ (Figs. I and 2). In all of the subjects studied FDP activated and Ala inhibited the enzyme. The interaction of FDP and Alat was dependent on the concentration of the substrate PEP. At low PEP concentration. there was net activation, whereas, at high PEP concentrations, there was net PK inhibition when $2 \mathrm{mM}$ Alat and $0.5 \mathrm{mM}$ FDP were present simultaneously in the reaction mixture. Leukocyte PK during pregnancy was relatively less sensitive to inhibition by Ala than the enzyme from leukocytes collected during the postpartum period. The switch-over from net inhibition

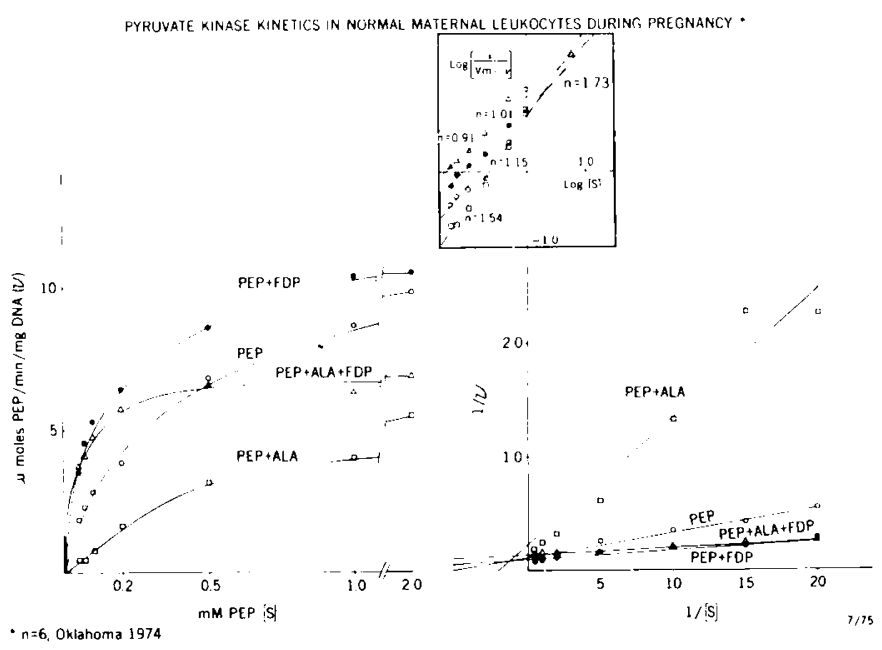

Fig. 1. v vs. phosphoenolpyruvate $(P E P)$, double reciprocal and Hill plots of leukocyte pyruvate kinase activity at 24.32 weeks of pregnancy. $\mathrm{O}-\mathrm{O}$, control; $\square-\square$, with $2 \mathrm{mM} \mathrm{L}$-alanine $(A L A)$; - , with $0.5 \mathrm{mM}$ fructose-1,6-diphosphate $(F D P): \triangle-\triangle$, with $2 \mathrm{mM} \mathrm{L}$-alanine and $0.5 \mathrm{mM}$ fructose-1,6-diphosphate. 


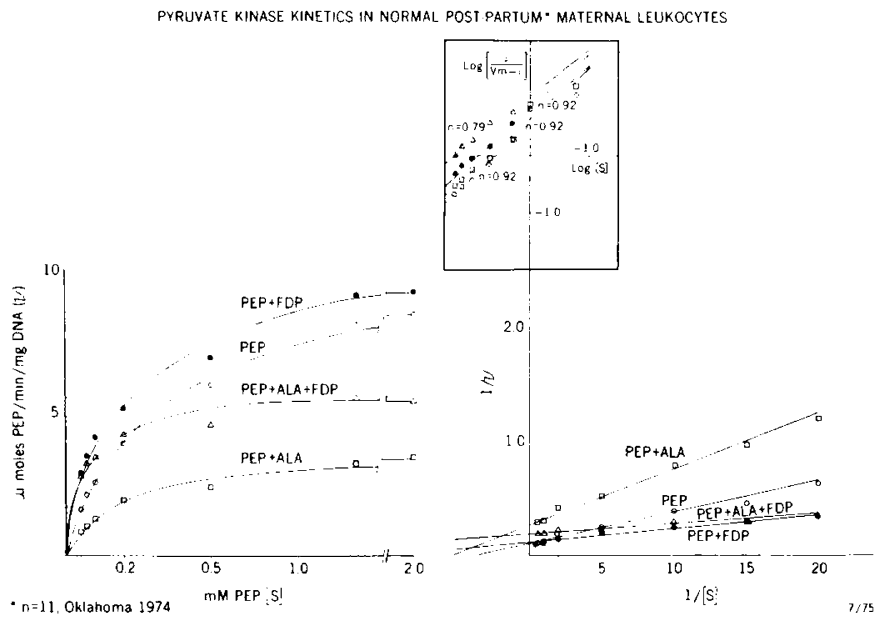

Fig. 2. v vs. phosphoenolpyruvate $(P E P)$ double reciprocal and Hill plots of leukocyte pyruvate kinase activity at 3 days to 6 weeks postpartum. $\mathrm{O}-\mathrm{O}$, control; $\square-\square$, with $2 \mathrm{mM} \mathrm{L-alanine}(A L A) ;-\square$, with $0.5 \mathrm{mM}$ fructose-1,6-diphosphate $(F D P) ; \triangle \longrightarrow \triangle$, with $2 \mathrm{mM} \mathrm{L}$-alanine and $0.5 \mathrm{mM}$ fructose-1,6-diphosphate.

Table 1. Effect of $0.5 \mathrm{mM}$ fructose-1,6-diphosphate (FDP) and 2.0 $m M$ L-alanine (Ala) on leukocyte pyruvate kinase during pregnancy and postpartum ${ }^{1}$

\begin{tabular}{|c|c|c|}
\hline Substrate and modifier & $\begin{array}{c}24-32 \text { weeks of } \\
\text { pregnancy } \\
\text { (6) }\end{array}$ & $\begin{array}{l}3 \text { days }-6 \text { weeks } \\
\text { postpartum } \\
\text { (11) }\end{array}$ \\
\hline & \multicolumn{2}{|c|}{$\begin{array}{c}\text { Maximal initial velocity } \\
(\mu \mathrm{mol} / \mathrm{min} / \mathrm{mg} \mathrm{DNA})\end{array}$} \\
\hline PEP & $8.99 \pm 2.02$ & $9.31 \pm 1.31$ \\
\hline PEP + Ala & $4.34 \pm 1.11^{2}$ & $3.68 \pm 0.73^{3}$ \\
\hline $\mathrm{PEP}+\mathrm{FDP}$ & $10.08 \pm 2.21$ & $8.86 \pm 1.38$ \\
\hline \multirow[t]{2}{*}{$\mathrm{PEP}+(\mathrm{Ala}+\mathrm{FDP})$} & $6.95 \pm 1.74$ & $5.43 \pm 0.93^{2}$ \\
\hline & \multicolumn{2}{|c|}{$\mathrm{K}_{0.5} \mathrm{M} \times 10^{-4} \mathrm{PEP}$} \\
\hline PEP & $1.92 \pm 0.22$ & $2.59 \pm 0.34$ \\
\hline $\mathrm{PEP}+\mathrm{Ala}$ & $4.93 \pm 1.40^{2}$ & $1.91 \pm 0.23$ \\
\hline $\mathrm{PEP}+\mathrm{FDP}$ & $0.81 \pm 0.07^{3}$ & $0.99 \pm 0.08^{3}$ \\
\hline $\mathrm{PEP}+(\mathrm{Ald}+\mathrm{FDP})$ & $0.41 \pm 0.18^{3}$ & $0.45 \pm 0.15^{3}$ \\
\hline
\end{tabular}

${ }^{1}$ Values are mean \pm SEM. Parentheses denote number of subjects. PEP: phosphoenolpyruvate.

${ }^{2} P<0.05$ (t-test) relative to PEP only.

${ }^{3} P<0.05$ ( $l$-test) relative to PEP only.

to net activation occurred at $0.5 \mathrm{mM} P E P$ in the sample obtained during gestation and at $0.2 \mathrm{mM}$ PEP in the postpartum sample (Figs. 1 and 2)

Table 1 demonstrates the effects of the two allosteric modifiers, FDP and Ala, added singly or combined, on the maximal pyruvate kinase activity per cell in leukocytes prepared during pregnancy and in the postpartum period. The $\mathrm{K}_{0.5}$ calculated for the enzyme obtained from the same subjects also is presented in Table 1 .

The effect of FDP and Ala on the response of leukocyte pyruvate kinase to increasing concentrations of PEP in Mexican mothers who delivered either normal or FM babies is illustrated in Figures 3 and 4 . The maximal enzyme velocity per cell and the $K_{0.5}$ of pyruvate kinase in the leukocytes of mothers of normal or FM babies and the effect of L-alanine and FDP on these enzyme parameters are presented in Table 2. The enzyme in leukocytes of FM mothers was equally sensitive to inhibition by alanine but was significantly less responsive to stimulation by FDP $(+10 \%$ vs $75 \%)$. FDP overcame the inhibition by alanine less effectively in leukocyte enzyme of mothers of FM babies than of normal babies $(-8 \%$ $v s+54 \%)$. The enzyme constants for the individual subjects were

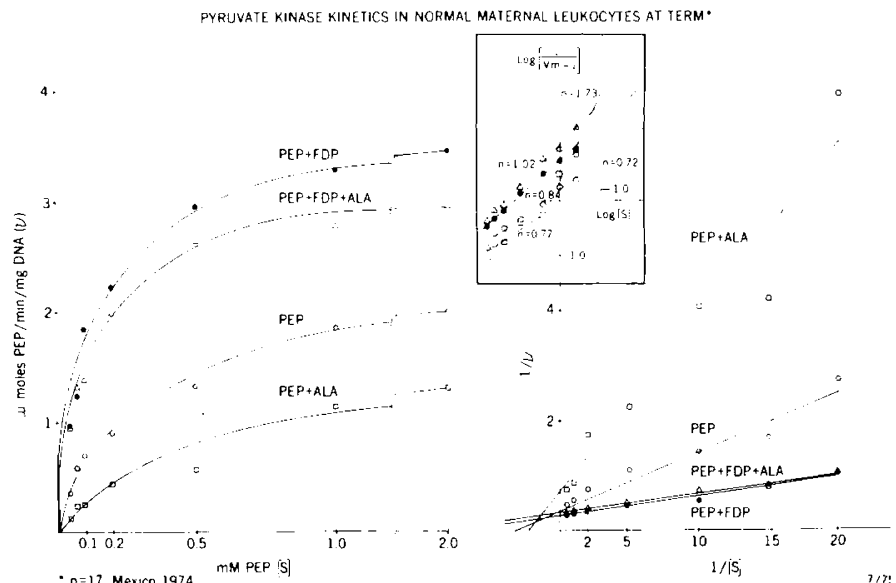

Fig. 3. $v$ vs. phosphoenolpyruvate $(P E P)$, double reciprocal and Hill plots of leukocyte pyruvate kinase activity at term in mothers of normal babies. $\bigcirc-O$. control: $\square-\square$, with $2 \mathrm{mM} \mathrm{L-alanine}(A L A)$; with $0.5 \mathrm{mM}$ fructosel,6-diphosphate $(F D P) ; \triangle \longrightarrow \triangle$, with $2 \mathrm{mM}$ $\mathrm{L}$-alanine and $0.5 \mathrm{mM}$ fructose-1,6-diphosphate.

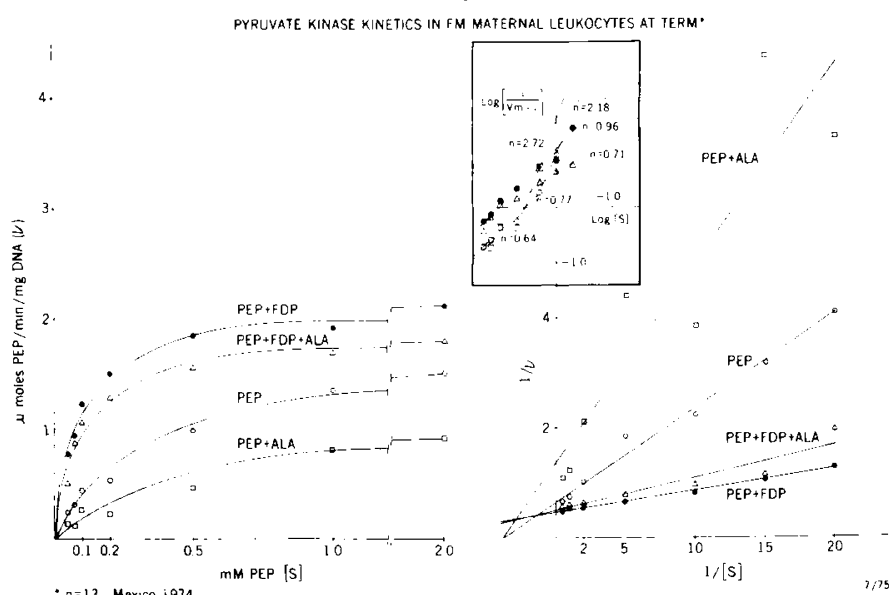

Fig. 4. v vs. phosphoenolpyruvate $(P E P)$, double reciprocal and Hill plots of leukocyte pyruvate kinase activity at term in mothers of fetally malnourished babies. $\mathrm{O}-\mathrm{O}$, control: $\square-\square$, with $2 \mathrm{mM}$ L-alanine $(A L A)$; - with $0.5 \mathrm{mM}$ fructose-1,6-diphosphate $(F D P) ; \triangle-\triangle$, with $2 \mathrm{mM}$ L-alanine and $0.5 \mathrm{mM}$ fructose-1,6-diphosphate.

Table 2. Effect of $0.5 \mathrm{mM}$ fructose-1,6-diphosphate (FDP) and 2.0 $m M$ L-alanine $(A l a)$ on leukocyte pyruvate kinase of mothers of normal and fetally malnourished $(F M)$ babies

\begin{tabular}{|c|c|c|}
\hline Substrate and modifier & $\begin{array}{l}\text { Normal mothers } \\
\text { (17) }\end{array}$ & $\begin{array}{c}\text { FM mothers } \\
\text { (14) }\end{array}$ \\
\hline & \multicolumn{2}{|c|}{$\begin{array}{c}\text { Maximal initial velocity } \\
(\mu \mathrm{mol} / \mathrm{min} / \mathrm{mg} \text { DNA })\end{array}$} \\
\hline PEP & $2.22 \pm 0.34$ & $2.01 \pm 0.44$ \\
\hline PEP + Ala & $1.17 \pm 0.23^{2}$ & $1.00 \pm 0.32^{2}$ \\
\hline $\mathrm{PEP}+\mathrm{FDP}$ & $3.88 \pm 0.56^{2}$ & $2.22 \pm 0.41^{3}$ \\
\hline \multirow[t]{3}{*}{$\mathrm{PEP}+(\mathrm{Ala}+\mathrm{FDP})$} & $3.42 \pm 0.48^{2}$ & $1.84 \pm 0.39^{3}$ \\
\hline & \multicolumn{2}{|c|}{$\mathrm{K}_{0.5} \mathrm{M} \times 10^{-4} \mathrm{PEP}$} \\
\hline & $2.93 \pm 0.57$ & $5.04 \pm 1.51$ \\
\hline PEP + Ala & $6.08 \pm 2.09$ & $4.42 \pm 1.04$ \\
\hline $\mathrm{PEP}+\mathrm{FDP}$ & $1.44 \pm 0.17^{2}$ & $1.06 \pm 0.20^{2}$ \\
\hline PEP + (Ala + FDP $)$ & $1.53 \pm 0.28^{2}$ & $1.48 \pm 0.51^{2}$ \\
\hline
\end{tabular}

${ }^{1}$ Values are mean \pm SEM. Parentheses denote number of subjects. PEP: phosphoenolpyruvate.

${ }^{2} P<0.05$ ( $t$-test) relative to $\mathrm{PEP}$ only.

${ }^{3} P<0.05$ (Mann-Whitney test) relative to response in normal mothers adjusted for changes in values of PEP only (23). 
adjusted by subtracting the values derived from the PEP alone for each point of each modified reaction in each subject. Since normal (parametric) distributions of the variables could not be assumed, the adjusted values were evaluated for difference by the MannWhitney $U$-test (22). Comparisons between the results in $\mathrm{Ok}$ lahoma and Mexico are difficult to interpret. The Oklahoma studies were done during pregnancy and postpartum: the Mexican studies, at term.

\section{DISCUSSION}

The activity of an enzyme in cell homogenates or extracts indicates the maximal activity the enzyme can achieve under the conditions of the assay, not what it does in the intact cell. Thus, observed changes in enzyme activity may be due to the interaction of numerous factors, such as an increase or decrease in the number of enzyme molecules: to the action of intracellular effectors of the enzyme; to previously inactive molecules: or to a change from one molecular form of the enzyme to another. Kinetic studies of enzyme regulation by physiologic effectors approximates a potential regulating mechanism of the enzyme in its cellular environment. Since PK is a rate-limiting enzyme in glycolysis, and a defect in its regulation in FM was previously observed (16), the effects of the modulators, L-alanine and FDP. on the activity of leukocyte pyruvate kinase during pregnancy, at term, and postpartum were examined in the present study.

During pregnancy, the type $M$ pyruvate kinase of peripheral blood leukocytes was activated by FDP and inhibited by L-alanine. This is in agreement with previous reports on pyruvate kinase in leukocytes isolated from the peripheral blood of human subjects $(3,6)$. However, in the present study, during normal pregnancy, the inhibition of pyruvate kinase by L-alanine was associated with a significant decrease in the maximal enzyme activity per cell which was partly overcome by FDP. In addition, FDP significantly reduced the $\mathrm{K}_{0.5}$ for PEP of leukocyte pyruvate kinase isolated during normal pregnancy and postpartum. Leukocyte pyruvate kinase during pregnancy was different in its response to L-alanine. which brought about an increase in $\mathrm{K}_{0.5}$ for PEP

The plots of PK activity vs PEP concentration given in Figure 1 are hyperbolic except in the presence of Ala, where a sigmoid $v$ is [S] curve is confirmed by a higher $n$ value (see Hill plots. Figs. I and 2). These data suggest that leukocyte pyruvate kinase during pregnancy exhibited increased cooperative interaction among the PEP binding sites in the presence of the allosteric modulator. L-alanine. The data on leukocyte pyruvate kinase during pregnancy are in agreement with reports showing that human leukocyte pyruvate kinase has sigmoid kinetics in the presence of L-alanine which change to hyperbolic with FDP (26). However, during the postpartum period, leukocyte pyruvate kinase kinetically resem-

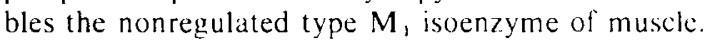

Previously we reported that the activity of leukocyte pyruvate kinase, with respect to the substrates PEP and ADP, was reduced in Mexican mothers of FM babies (16). In the present studies, the activity of leukocyte pyruvate kinase from mothers delivering FM babies (Table 2) was reduced with respect to the substrate, PEP Leukocyte pyruvate kinase from the FM mothers was significantly less responsive to activation by FDP, whether or not the inhibitor, Ala, was present (Fig. 4). The inhibition of pyruvate kinase by Ala could be partially overcome by FDP in the FM and normal mothers. FDP appeared to increase the affinity of the enzyme for PEP (i.e., decreased $K_{0.5}$ ). The $K_{0.5}$ differences between the normal and FM groups of mothers were, however, not statistically significant. It may be noted that the maximal enzyme activity per cell for Mexican mothers (Table 2) was lower than that for Oklahoma mothers (Table 1). Although the observation is interesting, the reason for the difference is not known. The same processing method, reagents, and instrumentation were used and all analyses were done by two of the authors (M. M. and J. M.) in both locales. Of course there are ethnic (Meztizo Mexican vs Western European origin American), dietary, and environmental (e.g., altitude: Mexico, D.F. $=7,000$ feet Oklahoma $=1,200$ feet) factors which could affect leukocyte metabolism. Age, parity, and weight gain were similar in both groups of mothers. The enzyme was studied during pregnancy and postpartum in Oklahoma mothers, but only at term in Mexican mothers.

The inhibition of pyruvate kinase by alanine during pregnancy may have physiologic significance, particularly with regard to the etiology of FM, where the enzyme is less responsive to the positive effector, fructose-1,6-phosphate. The human fetus depends upon glycolysis for energy supply, and derives its glucose from maternal metabolism. Although free amino acid levels may be low during pregnancy. the concentration of L-alanine is among the highest of all free amino acids in the plasma, amniotic fluid $(7,8,33)$, and leukocytes (29) of pregnant women and in cord blood (11,33). A glucose-alanine cycle has been postulated as a regulator of carbohydrate metabolism (7). The transamination of alanine, with formation of pyruvate, is reported to be reduced during pregnancy and may be impaired in FM babies (11).

It is likely that complex interactions between metabolism of the essential nutrients, glucose, and amino acids exist and involve the regulation of enzymes catalyzing the glycolytic and gluconeogenic pathways. In pregnant sheep, for example, glucose catabolism accounts for about $50 \%(12)$ and amino acid catabolism about $25 \%$ (10) of fetal oxvgen consumption during the last month of gestation. Starvation for 12 weeks at the beginning of the last quarter of pregnancy in the sheep led to either stillborn or underweight lambs at term. Reduced transplacental glucose uptake and increased amino acid catabolism (and, presumably, gluconeogenesis) by the fetus were observed within 4 days after maternal starvation began (23). The regulatory mechanisms involved are not known, but suggest a relationship between amino acid and carbohydrate metabolism in fetal organs which is modulated by maternal metabolism.

The data indicate that maternal leukocyte pyruvate kinase (M-type) during pregnancy is regulated by the same metabolic modifiers that modulate the activity of the L-type enzyme in liver.

The effects of the modifiers, alanine and FDP, on the kinetic behavior of leukocyle pyruvate kinase indicate a complex mode of interaction between the modifiers and the enzyme. Modulation of leukocyte pyruvate kinase during pregnancy by alanine and FDP was different from that observed postpartum. During pregnancy. but not postpartum, leukocyte pyruvate kinase kinetic data in the presence of L-alanine were sigmoid, not hyperbolic.

The enzyme in leukocytes of Mexican mothers who delivered normal and FM babies exhibited different kinetic responses to the allosteric modulators. The sensitivity of the enzyme to inhibition by alanine and the reduced response 10 stimulation by FDP in FM mothers could lead to a reduction in available metabolic energy required by rapidly replicating cells, like leukocytes. and by cells of the growing fetus if similar changes were present throughout pregnancy. The altered response of this enzyme to physiologic metabolic regulators suggests that FM can be associated with some relatively slight imbalance of nutrients and metabolites which modify response of key enzymes in critical pathways. In this sense, FM may not depend on obvious nutrient deficiency in a mother, but, rather, on nutrient imbalance, affecting susceptible enzymes in critical pathways of metabolism required for fetal cell replication and growth. The altered kinetic behavior of leukocyte pyruvate kinase in mothers of FM babies is consistent with the thesis that the metabolism of maternal leukocytes during pregnancy may serve as a "marker" indicating metabolic alterations in fetal cells. Further. the altered response of this enzyme to metabolic regulators suggests that response to allosteric effectors may provide a useful test to distinguish between mothers of FM and of normal babies as early as 2432 weeks of gestation. It is likely that the response of other allosterically regulated enzymes might also be altered by FM. The fetus depends on glycolytic metabolism, which is partially regulated by the activity of pyruvate kinase. Impaired pyruvate kinase activity appears to be a feature of FM, at least in rapidly replicating cells like leukocytes. If 
maternal leukocyte metabolism indeed reflects fetal cell metabolism, then it should be possible to modulate and monitor the activity of intracellular pyruvate kinase as well as of other regulatory enzymes for therapeutic purposes if FM can be identified early in pregnancy. These possibilities are being studied.

\section{SUMMARY}

Leukocyte pyruvate kinase activity is reduced and some kinetic characteristics of the enzyme are affected in mothers delivering FM babies. Allosteric inhibition of the enzyme was considered a possible explanation. The present report demonstrates that the leukocyte enzyme is modulated by two physiologic metabolites and is affected differently in mothers of FM babies. Leukocytes were isolated from the peripheral blood of women during pregnancy and postpartum, and in a separate study, at term from women who delivered normal or FM babies. In all cases, leukocyte pyruvate kinase was inhibited by $2 \mathrm{mM}$ Ala and activated by $0.5 \mathrm{mM}$ FDP: FDP completely reversed the inhibition by Ala. During pregnancy the alanine inhibition was associated with a decrease in the maximal enzyme activity, with an increased $\mathrm{K}_{0.5}$ per cell. Postpartum, the alanine inhibition also was associated with decreased maximal enzyme activity, but $\mathrm{K}_{0.5}$ was not affected. The activation of leukocyte pyruvate kinase by FDP was associated with a reduction in $\mathrm{K}_{0.5}$ at both times. Leukocyte pyruvate kinase in pregnancy is regulated by a different mechanism from that in the early postpartum period. In mothers of FM babies (body weight in grams $\div$ by gestational age in weeks $<68$ ), leukocyte pyruvate kinase at term was significantly less responsive to activation by FDP. Furthermore, the inhibition of the leukocyte enzyme by Ala was only partly overcome by the addition of FDP. These studies show that during pregnancy, at term, and in the early postpartum period, maternal leukocyte pyruvate kinase is regulated by Ala and FDP and that in mothers who delivered FM babies, the enzyme is less responsive to activation by FDP. The altered response of this enzyme to physiologic metabolic regulators suggests that FM can be associated with some relatively slight imbalance of nutrients and metabolites which modify response of key enzymes in critical pathways.

\section{REFERENCES AND NOTES}

1. Baehner, R. L., Gilman, H., and Karnovsky, M. L.: Respiration and glucose oxidation in human and guinea pig leukocytes: Comparative studies. J. Clin Invest., 46: 692 (1970)

2. Beck, W. S.: The cont rol of leuk ocyte glyculysis. J. Biol. Chem., 232:251 (1998)

3. Bigley, R. H., Stenzel, P., Jones, R. T., Campos, J. O., and Koler. R. D.: Tissue distribution of human pyruvate kinasc isoenzymes. Enzymol. Biol. Clin., 9: 10 (1968).

4. Bucher, T., and Pfleiderer, G.: Pyruvate kinase from muscle. In: S. P. Colowick and N. O. Kaplan: Methods in Enzymology. Vol. 1, p. 433 (Academic Press, New York, 1955).

5. Burton, K.: A study of the conditions and mechanism of the diphenylamine reaction for the calorimetric estimation of deoxyribonucleic acid. Biochem. J. 62: $315(1956)$

6. Campos, J. O., Koler, R. D., and Bigiey, R. H.: Kinetic difilerences between human red cell and leukocyte pyruvate kinase Nature, 208: 194 (1965).

7. Felig, P., Kim, Y. J., Lynch, V., and Handler, R.: Amino acid metabolism during starvation in human pregnancy. J. Clin. Invest., 5I: 1195 (1972).

8. Felig, P., Pozefsky, T., Marliss, E., and Cahill, G. F., Jr.: Alanine: Key role in luconeogenesis. Science, 167: $1003(1970)$

9. Giles. K. W.. and Meyer, A.: An improved diphenylamine method for the estimation of deoxyribonucleic acid. Nature, 206: 93 (1965)

10. Gresham, E. L., James, E. J., Raye, J. R., Battaglia, F. C., Makowski, E. L., and Meschia, G.: Production and excretion of urea by the fetal lamb. Pediatrics, 50 372 (1972).

11. Haymond, M. W., Karl, I. E., and Pagliara, A.: Increased gluconeogenic substrates in the small-for-gestational-age infant. N. Engl. J. Med., 29l: 32 (1974).
12. James, E. J., Raye, J. R., Gresham, E. L., Makowski, E. L., Meschia, G., and Battaglia, F. C.: Fetal oxygen consumption, carbon dioxide production, and glucose uptake in a chronic sheep preparation. Pediatrics, 50: 361 (1972).

13. Lowry, O. M., Rosebrough, M. J., Farr, A. L., and Randall, R. J.: Protein measurement with the Folin phenol reagent. J. Biol. Chem., 193: 265 (1951).

14. Mallette, L. E., Exton, J. H., and Park, C. R.: Control of gluconeogenesis from various precursors in the perfused rat liver. Biochem. J., 102: 942 (1969)

15. Melancov, S. B.: Detection of fructose-1,6-diphosphatase deficiency with use of white blood cells. N. Engl. J. Med., 286: 781 (1972)

16. Metcoff, $\mathrm{J}$ : Maternal leukocyte metabolism in fetal malnutrition: Nutrition and malnutrition; identification and measurement. Advan. Exp. Med. Biol. 49: 73 (1974).

17. Metcoff, J., Frenk, S., Antonowicz, I., Gordillo, G., and Lopez, E.: Relations of intra-cellular ions to metabolite sequences in muscle in kwashiorkor: A new reference for assessing the significance of intra-cellular concentrations of ions. Pediatrics, 26: 960 (1960).

18. Metcoff, J., Frenk, S., Yoshida, T., Pinedo, R. T., Kaiser, E. and Hansen, J. D L.: Cell composition and metabolism in kwashiorkor (severe protein-calorie malnutrition in children). Medicine, 45: 365 (1966).

19. Metcoff, J., Yoshida, T., Morales, M., Rosado, A.. Urrusti, J. Sosa, A., Yoshida, P., Frenk, P., Velasco, L.. Ward, A., and Y-Al-Ubaidi: Biomolecular studies of fetal malnutrition in maternal leuk ocytes. Pediatrics, 47: 180 (1971).

20. Metcoff, J., Wikman-Coffelt, J., Yoshida, T., Bernal, A., Rosado, A., Yoshida P., Urrusti, J., Frenk, S., Madrazo, R., Velasco L., and Morales, M.: Energy metabolism and protein synthesis in human leukocytes during pregnancy and in placenta related to fetal growth. Pediatrics, 51: 866 (1973).

21. Scrutton, M. C., and Utter, M. F.: The regulation of glycolysis and gluconeogenesis in animal tissues. Ann. Rev. Biochem., 37: 249 (1968).

22. Siegel, S.: Non-parametric Statistics for the Behavioral Sciences (McGraw-Hill, New York, 1956).

23. Simmons, M. A. Meschia, G.. Makowski, E. L.. and Battaglia, F. C.: Fetal metabolic response to maternal starvation. Pediat. Res., 8: 830, (1974)

24. Sosa, A.: Personal communication.

25. Tanaka, T., Harano, Y., Morimura, H., and Mori, R.: Evidence for the presence of two types of pyruvate kinase in rat liver. Biochem. Biophys. Res. Commun., 2l: 55 (1965).

26. Van Berkel, T. J. C. and Koster, J. F.: M-type pyruvate kinase of leukocytes: An allosteric enzyme. Biochim. Biophys. Acta, 293: 134 (1973).

27. Van Berkel, T. J. C.: Some kinetic properties of $\mathbf{M}_{2}$-type pyruvate kinase from rat liver at physiological $\mathrm{Mg} 2+$ concentration. Biochim. Biophys. Acta, 370 140 (1974).

28. Van Berkel, T. J. C., de Jonge, H. R., Koster, J. F., and Hulsmann, W. C.: Ki netic evidence for the presence of two forms of $\mathrm{M}_{2}$-pyruvate kinase in rat small intestines. Biochem. Biophys. Res. Commun., 60: 398 (1974).

29. Velazquez, A., and Metcoff, J.: Unpublished data (these studies were done on a similar (1975) but not the same (1974) groups of Mexican mothers. FDP levels were not measured

30. Yoshida, T., Metcoff, J., and Frenk, S.: Reduced pyruvic kinase activity, altered growth patterns of ATP in leukocytes, and protein-calorie malnutrition. Amer. J. Clin Nutr., 21: $162(1968)$

31. Yoshida, T.. Metcolf, J., Frenk. S., and de la Pena, C.: Intermediary metabolism and adenine nucleotides in leukocytes of children with protein-calorie mainutrition. Nature, 214: 5087 (1967)

32. Yosida. T. Metcoff, J. Morales, M. Rosado, A., Sosa, A., Yoshida, P.. Urrusti, J., Frenk, S., and Velasco, L.: Human fetal growth retardation. II. Energy metabolism in leukocytes. Pediatrics, 50: 559 (1972).

33. Young. M., and Prenton, M. A.: Maternal and fetal plasma amino acid concentrations during gestation and in retarded fetal growth. J. Obstet. Gynecol. Brit. Commonw., 76: 333 (1969).

34. Informed consent was obtained from patients in this study.

35. We are gratcful to our Mexican collaborators in the Maternal Malnutrition and Fetal Development Project, particularly Dr. Adolfo Rosado, in whose laboratories in the Department of Scientific Investigation at the Centro Medico Nacional of the Instituto Mexican del Sequro Social studies of the Mexican mothers were completed. Adolfo Rosado, Jr.. identified the patients and obtained the maternal and cord blood samples at parturition for us in Mexico. Leovardo Calzada, Gayle Burns, and Katherine Fowler assisted with the kinetic studies. Ardeth Wilson, David Schicdler, and William Reid helped develop the computer programs for the kinetic constants and statistical analyses

36. This research was supported by Grant POI-HD 06915 from the United States Public Health Service, Department of Health, Education and Welfare. National Institutes of Child Health and Human Development, to Dr. J. Metcoff. The work in Mexico was supported by a grant from Abbott International and Ross Laboratories to Dr. J. Metcoff.

37. This work was presented in part at the National Meeting of the Federation of American Societies for Experimental Biology. April 1974.

38. Requests for reprints should be addressed to: J. Metcoff, M.D. University of Oklahoma Health Sciences Center, P.O. Box 26901, Oklahoma City, Okla. 73190 (USA)

39. Accepted for publication December 1, 1975 